\title{
Execute of Cooling Vacuum Crystallization (CVC) in Place of C-Cooling Crystallizers for White Sugar Production and Energy Saving in the Beet Sugar Industry
}

\section{Yassien M. Temerk ${ }^{1}$, Ibrahim D. Abdullah ${ }^{2}$, Osama Z. El- Abdein $^{3}$}

\author{
${ }^{1}$ Faculty of Science, Assiut University, Egypt \\ ${ }^{2}$ Sugar and Integrated Industries, Hawamdya, 6 October \\ ${ }^{3}$ Al Khaleej Sugar Co. AKS, Jebel Ali port, Dubai, U.A.E \\ ozein51@gmail.com
}

\section{Abstract}

This article reports the development at Al-Khaleej sugar company AKS between 2016 and 2020 in low-temperature sugar crystallization and incorporating of CVC technology in the new AKS beet sugar project in Egypt, Online 2021. The new project includes three continuous vacuum crystallizers followed by $\mathrm{CVC}$, to be used in place of $\mathrm{C}$-cooling crystallizers. All details, features, and results of the new sugar house crystallization scheme have been listed in the paper.

Keywords: Crystallization, Industrial process design, Food industry, Process development, manufacturing.

\section{Introduction}

\section{Sugar crystallization techniques:}

Crystallization of sucrose from aqueous sugar solutions occurs in various ways, where saturation solubility must be exceeded:

1. Evaporating crystallization: This occurs in a vacuum and involves the processes of mass transfer and water evaporation. The vacuum helps to maintain a low temperature to minimize color formation and degradation of sucrose during the process.

2. Cooling crystallization: It occurs under atmospheric pressure, involving a decrease in sucrose solubility and raising supersaturation required for crystallization by reducing temperature through indirect cooling. The dry substance content of the massecuite remains constant. 
3. Evaporation/cooling (flash) crystallization: It occurs in a vacuum and involves water evaporation through expansion. Water is evaporated and the dry substance content of massecuite rises by lowering vapor space pressure, supplemented by a fall in massecuite temperature due to evaporation enthalpy [1].

The comparison of all changes associated with the crystallization of pure sucrose starting from an unsaturated point is shown in table I.1. The specific change of each crystallization process is summarized as follows:

Cooling: decrease in solubility

Evaporation: water removal by evaporation

Flash evaporation: decrease in solubility, water removal by expansion

Table I.1. Solubility, concentration, and Temp. changes in sucrose crystallization

\begin{tabular}{|l|c|c|c|c|}
\hline & Unsaturation & \multicolumn{3}{|c|}{ Saturation } \\
\hline & Unsaturated & Cooling & Flash & Evapo \\
\hline Temperature ${ }^{\circ} \mathrm{C}$ & $\mathbf{7 5}$ & $\mathbf{5 0}$ & $\mathbf{6 0}$ & $\mathbf{7 5}$ \\
\hline Brix \% & $\mathbf{7 2 . 1 2}$ & $\mathbf{7 2 . 1 2}$ & $\mathbf{7 4 . 2 6}$ & $\mathbf{7 7 . 5 9}$ \\
\hline$(\mathrm{S} / \mathrm{W}) \mathbf{g} / \mathbf{g}$ & $\mathbf{2 . 5 8 6}$ & $\mathbf{2 . 5 8 6}$ & $\mathbf{2 . 5 8 6}$ & $\mathbf{3 . 4 6 2}$ \\
\hline$(\mathrm{S} / \mathrm{W})_{\text {Sat }}$ g/g & $\mathbf{3 . 4 6 2}$ & $\mathbf{2 . 5 8 6}$ & $\mathbf{2 . 8 8 5}$ & $\mathbf{3 . 4 6 2}$ \\
\hline $\begin{array}{l}\mathbf{Y}_{\mathrm{p}} \% \\
\text { Supersaturation }\end{array}$ & $\mathbf{0 . 7 4 7}$ & 1 & 1 & 1 \\
\hline $\begin{array}{l}\text { Sugar Conc. - } \\
\text { brix }\end{array}$ & & decrease & decrease & no change \\
\hline Solubility & & no change & increase & increase \\
\hline Temperature & & decrease & decreas & no change \\
\hline
\end{tabular}

Returns from cooling crystallization than steam consumption reduction are:

- Achieving $\pm 3 \%$ crystal content resulted by evapocrystallization

- Pan's electricity reduction associated with low massecuite brix

- Low sugar color, less water of crystal's washing, and low sugar Temp. 
- Sugar drying and conditioning low energy resulting from low sugar Temp.

- Low coefficient of variation "CV" of sugar crystals than that of evapo-crystallization by the slow crystal growth rate [11].

The limitations of cooling and flash cooling crystallization are hard to handle while curing of the massecuite and its low fluidity are related to rising in viscosity. The viscosity limits allow achieving slightly higher or the same common massecuite crystal content achieved by traditional high-temperature boiling but at lower massecuite brix rather than achieving more crystal content.

\section{Flash/cooling crystallization operating principle in practice}

Many authors pointed out that a 13 to $30 \%$ increase in magma's crystal content could be achieved by continuous run-off feeding to $25 \%$ of magma mass and cooling to $\Delta \mathrm{T} 25$ temperature degree differences. The material and energy balances have all suggested a very lucrative economical gain by using cooling crystallizers to replace two of four boiling cane sugar refineries [35], [7-8].

Current use of CVC: Using Fives Cail Babckok "FCB" horizontal crystallizer in European beet sugar plants for A sugar boiling in British sugar and Zucker German company and A, B, and $\mathrm{C}$ sugar boiling in three French companies. New R1 continuous sugar crystallizer working under vac. 0.1 bar a in $\mathrm{Al}$ Khaleej Sugar Co.

Crystal growth was reported for A, B, and C strikes as FCB:

15:20\% A Masc. mass using recycled run off 20\% Masc. flow in $1 \mathrm{hr}$

10:15\% B Masc. mass using recycled run off 20\% Masc. flow in $1 \mathrm{hr}$

10:15\% C Masc. mass using recycled run off 10\% Masc. flow in $4 \mathrm{hr}$ 


\section{Experimental work}

\section{Modeling new crystallization scheme with CVC concept of Canal sugar company, Egypt}

A set of pilot tests on a low temperature and flash cooling of sucrose crystallization have been performed at Al Khaleej Sugar Co. AKS, Dubai, UAE through 2016 to 2020 to evaluate the efficiency and applicability of this process for white sugar production. Most of the results showed big benefits reported in the previous article "Cooling crystallization opportunities for white sugar production" [10]. AKS designing the sugar crystallization scheme of the new beet sugar project "Canal sugar, Egypt, under construction and be online 2021" to run sugar crystallizers under low vacuum pressure than the traditional process.

Main operation characteristics of the sugar house of canal sugar plant are:

- Sliced beet 1500 ton/h - Overall sugar recovery minimum 83\%

- Sugar yield $\pm 15 \%$ O.B- Molasses $\pm 5.5 \%$ O.B- Mol. Loss \pm $2.5 \%$ O.B

- B sugar is packed with A sugar as white sugar

- Granular activated carbon GAC system is used for thick juice decolorization to enable get white sugar color 45 IU

- New continuous sugar crystallizers running under Vac. 100 mbarafor $1^{\text {st }}$ and $2^{\text {nd }}$ strikes while $3^{\text {rd }}$ strike running under Vac. 200 mbar a

- Continuous vacuum cooling crystallizers CVC are used in place of traditional C-cooling crystallizers and also for $1^{\text {st }}$ and $2^{\text {nd }}$ strikes after the continuous crystallizer, it runs under a deep vacuum of 50 mbar a

- Separate mechanical vapor compression MVR for each crystallization loop to create the required vacuum at all sugar crystallizers in a closed-loop, the recompressed vapor of low pressure 350 mbar a recycled back to the sugar crystallizers. 

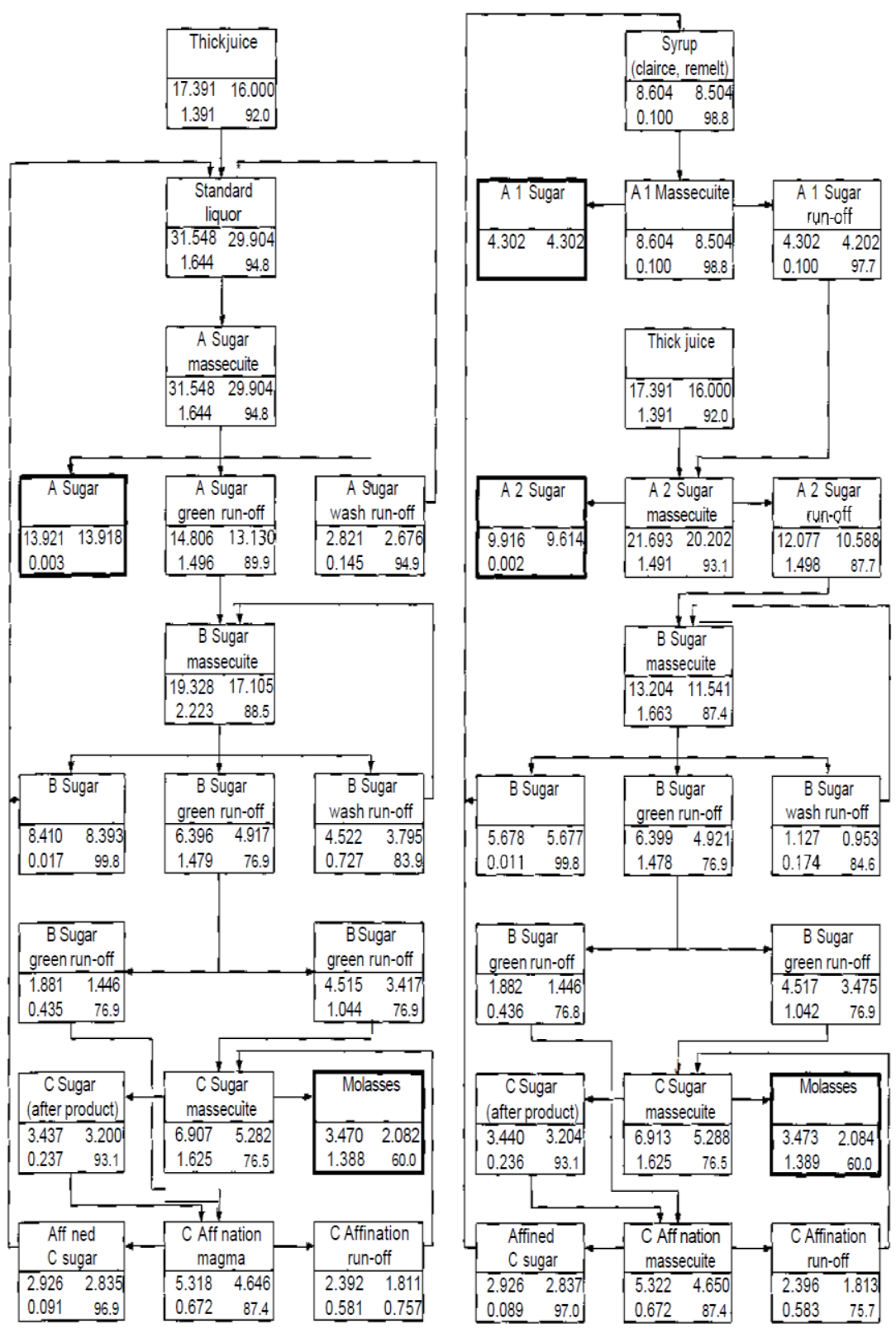

Fig.II.1. Standard beet sugar three boiling schemes [13] (One-grade product at the left and two grade products at the right) 


\section{Three conventional boiling schemes for white sugar production}

In practice, there are two common schemes for white sugar production from sugar beet, as shown in Fig. II.1. Using C-cooling crystallizers after evapo-crystallizer, the commonly used scheme is for one-grade sugar product and the second for two-grade sugar products. Water evaporation for one sugar grade product reported $11 \mathrm{~kg}$ per $100 \mathrm{~kg}$ beet, while for two-grade sugar products it was $15 \mathrm{~kg}$ per $100 \mathrm{~kg}$ beet. Steam consumption is estimated from water evaporation, which is slightly higher. Sugar yield for both crystallization schemes is nearly the same $14.2 \mathrm{~kg}$ per $100 \mathrm{~kg}$ beet. Sugar crystal washing for both represents $3 \mathrm{~kg}$ per $100 \mathrm{~kg}$ beet, indicating makeup water of boilers. Table II.1 summarizes crystallization parameters and quantities per $100 \mathrm{~kg}$ of beet for conventional crystallization schemes working under 200 mbar a, includes $\mathrm{C}$-cooling crystallizers and the new crystallization scheme includes CVC working under 100 mbar a. 
Table II.1. Parameters of conventional schemes and the new scheme include CVC

\begin{tabular}{|l|c|c|c|}
\hline \multicolumn{1}{|c|}{$\begin{array}{c}\text { Parameter before } \\
\text { centrifuges }\end{array}$} & $\begin{array}{c}\text { One } \\
\text { product }\end{array}$ & Two products & $\begin{array}{c}\text { New } \\
\text { scheme }\end{array}$ \\
\hline A massecuite mass ton & 34.66 & 33.11 & 14.17 \\
\hline A massecuite brix \% & 91.5 & 91.5 & 88.81 \\
\hline A massecuite purity \% & 94.8 & A1 98.8,A2 93 & 89.77 \\
\hline $\begin{array}{l}\text { A Crystal content \% total } \\
\text { massecuite }\end{array}$ & 43.16 & 45.94 & 47.2 \\
\hline B massecuite mass ton & 20.78 & 14.2 & 20.97 \\
\hline B massecuite brix \% & 93 & 93 & 89.7 \\
\hline B massecuite purity \% & 88.5 & 87.4 & 85.6 \\
\hline $\begin{array}{l}\text { B Crystal content \% total } \\
\text { massecuite }\end{array}$ & 43.47 & 43 & 41.3 \\
\hline C massecuite mass ton & 7.26 & 7.27 & 10.64 \\
\hline C massecuite brix \% & 95 & 95 & 92.65 \\
\hline C massecuite purity \% & 76.5 & 76.5 & 72.61 \\
\hline $\begin{array}{l}\text { C Crystal content \% total } \\
\text { massecuite }\end{array}$ & 50.38 & 50.31 & 32.9 \\
\hline Final molasses brix \% & 82 & 82 & 81.07 \\
\hline Final molasses purity \% & 60 & 60 & 61.74 \\
\hline Sugar Yield \% O.B. & 13.91 & 14.2 & 14.78 \\
\hline Molasses quantity \% O.B. & 4.23 & 4.23 & 5.92 \\
\hline Molasses loss \% O.B. & 2.08 & 2.08 & 2.96 \\
\hline $\begin{array}{l}\text { Total massecuite quantity } \\
\text { \% O.B. }\end{array}$ & 62 & 55 & 45.77 \\
\hline $\begin{array}{l}\text { Total water evaporation } \\
\text { \% O.B. }\end{array}$ & 11 & 15 & 7.42 \\
\hline $\begin{array}{l}\text { Sugar crystal washing \% } \\
\text { O.B. }\end{array}$ & 2.8 & 2.47 & 2.34 \\
\hline
\end{tabular}

Note: Water evaporation of CVC scheme is 7.42 tons of evapo-crystallizers that use heating steam; thus, with add $0.81 \mathrm{CVC}$ vapors, total evaporation is 8.23 tons. 


\section{CVC crystallization scheme considerations and description}

There is thick juice after evaporators filter in 50-micron filters; $62 \%$ is sent to the 2nd strike to maintain high purity and quality of B massecuite and accordingly, B sugar product; while, $38 \%$ is diverted to 1 st strike, mixed with $\mathrm{A}$ wash run-off and affinated $\mathrm{C}$ sugar as the conventional process. Sugar boiling occurs in $1^{\text {st }}$ continuous crystallizer under deep vacuum 100 mbar a and low-pressure steam of 350 mbar a; massecuite leaves the continuous crystallizer at low temperature of $53^{\circ} \mathrm{C}$, brix $89.7 \%$ and crystal content $51 \%$ massecuite. The $2^{\text {nd }}$ strike boiling also runs under vacuum 100 mbar a and massecuite leaves sugar crystallizer at $55^{\circ} \mathrm{C}$, brix $90.8 \%$ and crystal content $45.3 \%$ massecuite, while $3^{\text {rd }}$ strike boiling runs under vacuum 200 mbar a and massecuite leaves sugar crystallizer at $88^{\circ} \mathrm{C}$, brix $95.05 \%$ and crystal content $28.51 \%$ massecuite, as shown in Fig. II.2.

The $1^{\text {st }}$ strike massecuite enters the first compartment of $\mathrm{CVC}$ and is mixed with hot A run-off at $88^{\circ} \mathrm{C}$, which undergoes flash evaporation by high vacuum 80 mbar a; with the continuous feeding of A massecuite and A run-off, the massecuite moves to the next compartment also by the high suction force of deep vacuum 50 mbar a and continue in fed with hot run-off and flash evaporation. The crystal growth of $16.7 \%$ original A massecuite is obtained from recirculation of $\mathrm{A}$ runoff that represents $30 \% \mathrm{~A}$ massecuite and within one-hour retention in each CVC. Total retention of A massecuite is 1.75 hours achieved by using two CVC flash vessels. As a result of the recirculation, some purity drops from $92.5 \%$ to $89.77 \%$, and also brix drops from $89.67 \%$ to $88.81 \%$.

The same scenario precedes $2^{\text {nd }}$ and $3^{\text {rd }}$ strikes where $25 \%$ original massecuite is recirculated into CVCs and feeds the massecuite, crystal growth is $11.2 \%, 44.37 \%$ entering the massecuite of $2^{\text {nd }}$ and $3^{\text {rd }}$ strikes achieved within retention 1.25 , 3.75 hours for $2^{\text {nd }}$ and $3^{\text {rd }}$ strikes, respectively, using two CVC flash vessels for $2^{\text {nd }}$ strikes and three vessels for $3^{\text {rd }}$ strike. For $2^{\text {nd }}$ strike, purity drops from $87.97 \%$ to $85.6 \%$, and brix drop from 
$90.79 \%$ to $89.7 \%$ while for $3^{\text {rd }}$ strike the purity drop from $75 \%$ to $72.61 \%$ and the brix drop from $95.05 \%$ to $92.65 \%$.

\section{The following points are taken into consideration}

- The purity figure of the three sugar crystallizers is considered to be within limits of the conventional process to get the desired highest crystal growth from each crystallizer, while for CVCs there is expected purity drop after each CVC, but within the operational limits of centrifuges.

- The conventional sugar house operation scheme of A sugar product as shown in Fig. II. 2 involves C-cooling crystallization after $\mathrm{C}$-crystallizer where massecuite is cooled from $85^{\circ} \mathrm{C}$ to $45^{\circ} \mathrm{C}$ by cold water circuit (within 40 hours), which recovers the molasses sugar to get the purity of 58\%. C sugar is affinited to raise its purity from $94 \%$ to $98 \%$, recycled to A boiling.

- The $1^{\text {st }}$ and $2^{\text {nd }}$ continuous sugar crystallizations are performed under vacuum 100 mbar a and CVCs under vacuum 50 mbar a to get the highest sugar yield form each strike with the lowest energy.

- Full run-offs separation, with most green run-off quantity of high purity, are sent to the next strike and only little wash runoff quantity of high purity are recycled back to the same strike because of the following reasons:

- To maintain the massecuite purity of the next boiling high as much as possible, as B boiling of one of the sugar products.

- To get the highest crystal growth and sugar yield, obtained at higher massecuite purity limits.

- To maintain the purity of B boiling (product's strike) high, as with $30 \%$ A run-off circulation A in A-CVC run off purity reaches $79 \%$ so recirculation is increased in $\mathrm{B}-\mathrm{CVC}$, then reaches the highest percentage in C-CVC (36\% on Masc.).

- Run-offs heated to $88^{\circ} \mathrm{C}$ before being fed into CVCs to undergo flash crystallization requirements. 
- Crystal content, massecuite and run-off brix values, and crystal growth are not assumed and calculated form sucrose solubility using Viklund coefficients and mathematical model, shown in figures I.3 and I.4.

- Modeling of sugar continuous crystallizers and CVC-based on linear crystal growth approach [16].

- Formulas for estimation of end massecuite brix form sucrose solubility [9].

Seeding brix $=(\mathrm{S} / \mathrm{W}$ ratio $\times 100) /(\mathrm{S} / \mathrm{W}$ ratio + feed purity $)$

$\%$ II.1

End ML purity $=$ Feed liquor purity $-(\mathrm{CC} \times$ sugar purity/100 $)$ $\underline{\times 100 \%}$ II.2 $100-\mathrm{CC}$

End ML brix $=100-($ End ML purity $\times 100) /($ End ML purity $+\mathrm{S} / \mathrm{W}) \% \quad$ II.3

End massecuite brix = End ML brix $\times 100 \quad \%$ II.4

(End ML brix - End ML brix $\times$ MLso /100+ MLso)

ML: mother liquor - So: sugar solubility - CC: crystal content S/W: sugar water ratio. 


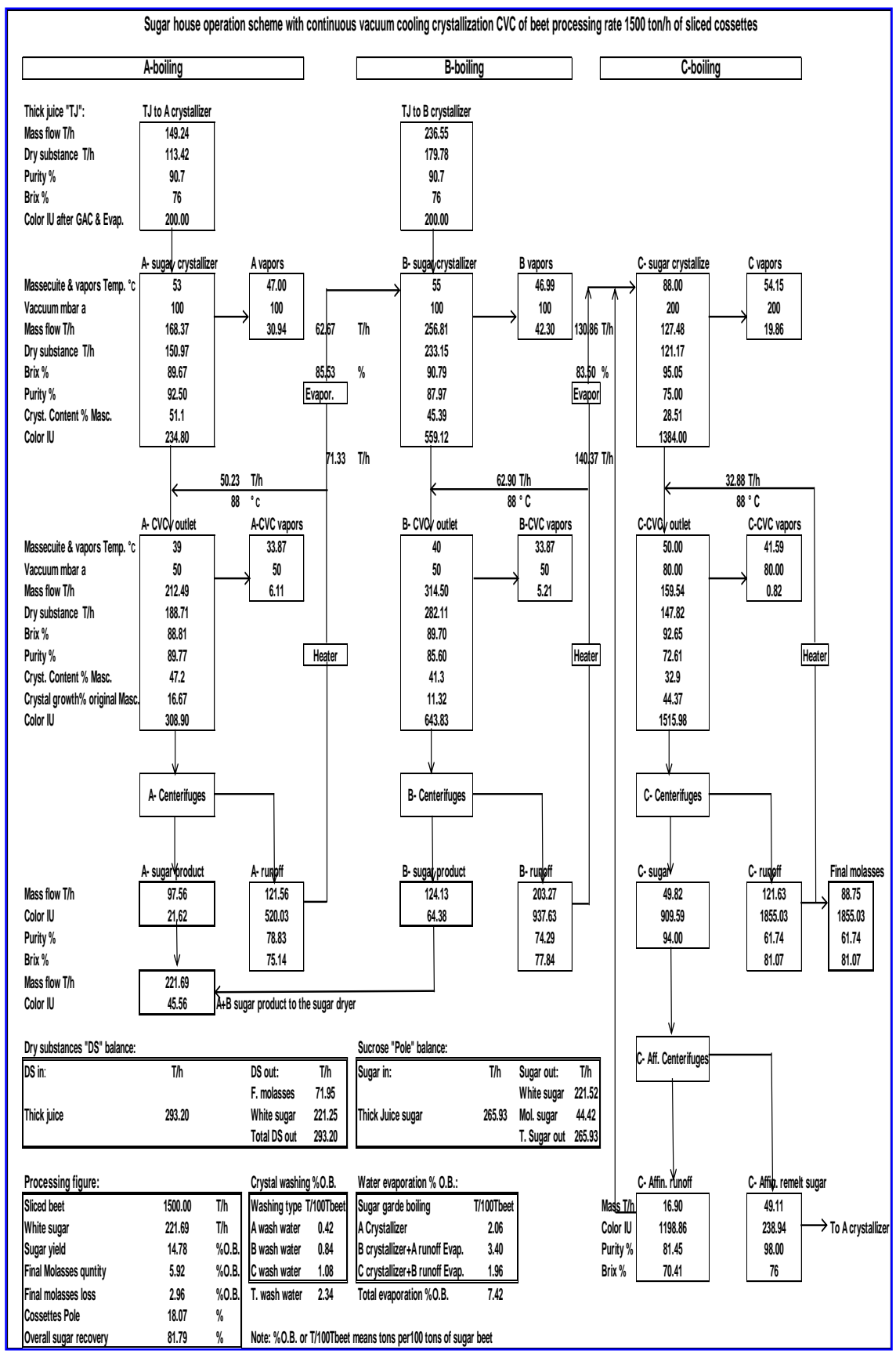

Fig. II.2. Sugar house operation scheme involves the CVC concept. 
3. Assessment of low-temperature crystallization for white sugar production

Measures that could be used for evaluation of the sugar crystallization process are productivity in terms of crystal content and energy consumption and quality in terms of sugar color, moisture, and grain size. Massecuite crystal content, brix, and purity values of existing VKT evapo-crystallizers run under vacuum 200 mbar a, equivalent to working temperature 75 to $82^{\circ}$ $\mathrm{C}$, varying with purity is shown as follows [6]:

$$
\begin{aligned}
& 1^{\text {st }} \quad \text { strike: Pu 95 \% - CC 53.5\% - brix 91\% } \\
& 2^{\text {nd }} \quad \text { strike: Pu 89.5 - CC 49.5\% - brix 92.5\% } \\
& \text { 3rd } \quad \text { strike: Pu 77\% - CC 39.8\% - brix 95\% }
\end{aligned}
$$

The slightly low crystal content values achieved from the new sugar crystallizers working under deep vacuum 100 mbar a ( 1 st $\& 2$ nd strikes) related to lower purity than the existing one are also achieved at lower brix values as cleared from the scheme shown in fig. II.2. For the 3rd strike that is run the same as the existing under vacuum 200 mbar a crystal content is slightly low, also due to its low purity resulting from repeated run-offs' recirculation in CVCs. All the parameters, considering purity differences, indicate that the new sugar crystallizer gives the same crystal content referenced values. Also, lower brix than existing working systems indicates achieving lower water evaporation and accordingly, lower steam and energy consumption, cleared from table II.1. Total water evaporation is $7.4 \%$ OB versus $11,15 \%$ OB.

$$
\begin{aligned}
& 1^{\text {st }} \text { strike: Pu 92.5 \% - CC 51.1\% - brix 89.67\% } \\
& 2^{\text {nd }} \text { strike: Pu 88.97 - CC 45.4 \% - brix 90.79\% } \\
& 3^{\text {rd }} \text { strike: Pu 75\% - CC } 28.5 \% \text { - brix } 95.05 \%
\end{aligned}
$$

For the assessment of CVC replacement in place of Ccooling crystallizers, crystal growth resulting from each $\mathrm{CVC}$ is considered as the increase in the original crystal content after each evapo-crystallizer; thus, crystal content after the increase is calculated from the scheme given in Fig. II.2. and table II.1. as follows: 
$1^{\text {st }}$ strike: Original CC 51.1 - mass 168.37 - CVC crystal growth $16.67 \%$

A sugar $=168.37 \times 51.1 / 100=86.04$ ton

Crystal growth $=86.04 \times 16.67 / 100=14.34$ ton

New A crystal content $=(86.04+14.34) \times 100 / 168.37=\underline{59.62 \%}$

$2^{\text {nd }}$ strike: Original CC 45.39 - mass 256.81 - CVC crystal growth $11.32 \%$

B sugar $=256.81 \times 45.39 / 100=116.57$ ton

Crystal growth $=116.57 \times 11.32 / 100=13.20$ ton

New B crystal content $=(116.57+13.26) \times 100 / 256.81=\underline{\mathbf{5 0 . 5 3 \%}}$

$3^{\text {rd }}$ strike: Original CC 28.51 - mass 127.48 - CVC crystal growth $44.37 \%$

C sugar $=127.48 \times 28.51 / 100=36.34$ ton

Crystal growth $=36.34 \times 44.37 / 100=16.13$ ton

New $C$ crystal content $=(36.34+16.13) \times 100 / 127.48=\underline{\mathbf{4 1 . 1 5 \%}}$

Thus, from this estimation, it is clear that $1^{\text {st }}$ and $2^{\text {nd }}$ strikes due to evapo-crystallizers and CVCs give slightly higher crystal content than in reality, while $3^{\text {rd }}$ strike after evapo-crystallizer and CVC give CC slightly lower than $\pm 48 \%$, achieved after cooling crystallizers in reality. It appears that a slight increase in CC of the $1^{\text {st }}$ strike compensates the slight decrease in the $\mathrm{CC}$ of the $3^{\text {rd }}$ strike, making the overall recovery, sugar yield, and molasses loss lie within standard operation limits with advantages of low steam consumption and low sugar temperature and color.

\section{Results and discussions}

Many authors and articles pointed out high productivity achieved from running sugar crystallization under low vacuum pressure. This high productivity is offered in the form of high crystal growth or content with less energy and steam consumption $[2,9,14]$. From data of the new CVC scheme in fig.II.2 and of conventional sugar crystallization scheme in table II.1, we can conclude:

1. Crystal content values of $1^{\text {st }}, 2^{\text {nd }}$, and $3^{\text {rd }}$ strikes (51.1- 45.4 28.51), run under low vacuum pressure, are slightly higher 
than values obtained from conventional sugar strikes, performed under higher vacuum (46- 43- 33). Higher crystal content values are also achieved at lower brix values than conventional strikes.

2. Water evaporation by the new CVC scheme is 7.4 versus 11 and $15 \%$ O.B. of one and two grade products, respectively; meaning $30-50 \%$ reduction in steam consumption could be achieved than conventional operation.

3. Sugar crystal wash water quantity by new CVC scheme is 2.34 versus 2.47 and $2.8 \%$ O.B. of one and two-grade product conventional schemes, respectively, indicating a 5.3 to $16.42 \%$ reduction in water consumption.

4. The crystal content of the $3^{\text {rd }}$ strike after cooling crystallizers is $50 \%$, while that by CVC is 32.9 . This is clarified before by adding gained crystal growth by $\mathrm{C}-\mathrm{CVC}$ the crystal content actual after $\mathrm{C} C \mathrm{CVC}$ will be $41.15 \%$ related to the original massecuit of $\mathrm{C}$ sugar evapo-crystallizer.

5. Operational KPI parameters meet standards, except for molasses loss, which is 2.96 versus $2.08 \%$ O.B. of conventional schemes.

6. The purity figure of the three strikes is high and within operation limits of conventional crystallization schemes to get the highest crystal growth before the purity drop by run-offs circulation in CVCs.

Energy consumption of European beet sugar factories was reported $6 \mathrm{MJ}$ per $\mathrm{kg}$ of white sugar and $0.87 \mathrm{MJ}$ per ton of beet (240 KWh per ton of beet) including pulp drying and pelting, which requires $98 \mathrm{kWh}$ per ton of beet, while electricity consumption was reported $33 \mathrm{kWh}$ per ton of beet at steam consumption $25 \%$ O.B.[15]. Steam consumption of Egyptian sugar factories is $32 \%$ O.B. and energy consumption is $7.85 \mathrm{MJ}$ per $\mathrm{kg}$ of white sugar and 1.1 MJ per ton of beet including pulp drying and pelting. Considering the high electricity of MVRs, the electrical consumption could be more than $33 \mathrm{kwh}$ per ton of beet, while steam consumption could be reduced to $60 \%$ by MVR closed loops at evaporation and crystallization. Thus, it is expected to be 
reduced from $32 \%$ to $13 \%$ O.B. and energy consumption to be reduced from 1.1 to $0.66 \mathrm{MJ}$ per ton of beet.

The effect of working temperature on the crystal growth of $3^{\text {rd }}$ strike sugar crystallization of the same inputs (purity, mass, brix, heating surface area) and performed under two different low and high vacuum conditions indicate higher productivity at low Temp. Higher crystal content of sugar crystallization performed under deep vacuum 100 mbar a $34.45 \%$ vs. $30.43 \%$ with lower steam consumption 22.57 Ton vs 25.92 of that proceeded at higher vacuum 200 mbar a. lower massecuite brix 93.1\% achieved with deep vacuum vs $95.1 \%$ with high vacuum.

Fig. III.1. Linear crystal growth of continuous sugar crystallizer of $1^{\text {st }}$ strike
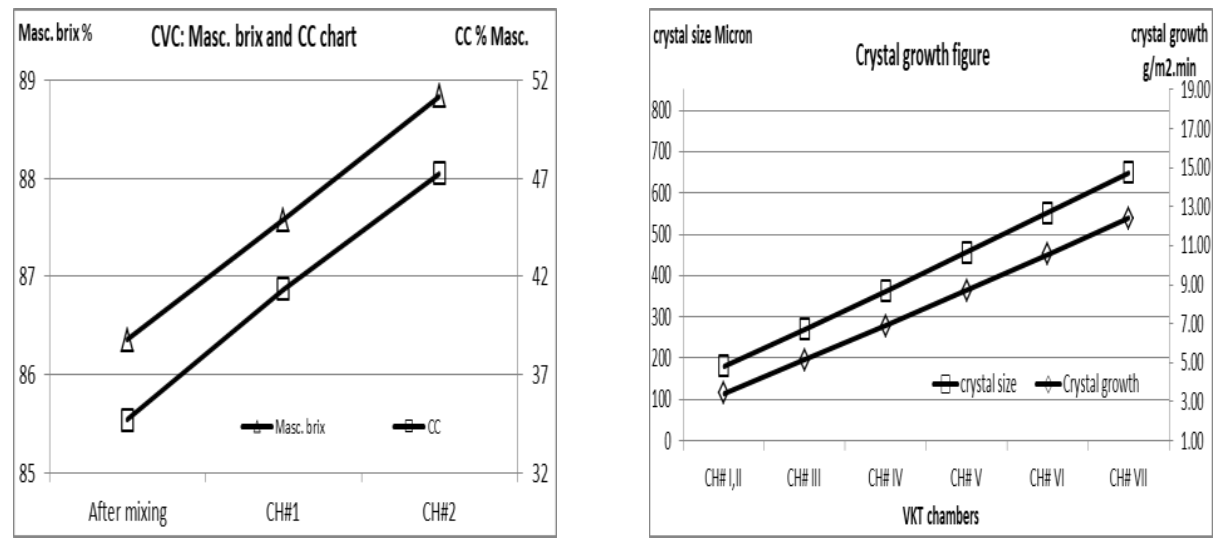

Modeling of the new sugar crystallizer and CVC was generated based on a linear crystal growth approach, and as seen from Fig. III. 1 , the crystal growth rate of $1^{\text {st }}$ boiling is $1.4 \mathrm{~g} / \mathrm{m} 2 . \mathrm{min}, 2^{\text {nd }}$ boiling is $1.33 \mathrm{~g} / \mathrm{m} 2 . \mathrm{min}$, and $3^{\text {rd }}$ boiling is $0.66 \mathrm{~g} / \mathrm{m} 2 . \mathrm{min}$. They meet crystal growth rates of existing-working sugar crystallization systems.

\section{Replacement of C-cooling crystallizers with CVC}

The role of cooling crystallizers in the $3^{\text {rd }}$ strike of low purity is to complete sucrose exhaustion after evapocrystallization, not capable to exhaust all sucrose from molasses. 
By extended indirect cooling with reduction of massecuite temperature the sucrose solubility decreases and sucrose concentration of mother liquor increases to supersaturation, so new additional sucrose molecules diffuse towards the surface of the existing sugar crystals and deposit on it. After cooling crystallizers, the purity degree is 10 degrees and crystal content increases up to $48 \%$ starting from $32 \%$. Closed cooling water loop used for cooling massecuite from 85 to $45^{\circ} \mathrm{C}$ with a cooling rate of $1^{\circ} \mathrm{C} / \mathrm{h}$, so huge capacities are required to satisfy 40 hours retention [12].

As mentioned before, considering the gain in the crystal growth by $3^{\text {rd }}$ strike or $\mathrm{C} \mathrm{CVC}$ added to the original $3^{\text {rd }}$ strike or $\mathrm{C}$ massecuite, the real crystal content after $\mathrm{C} \mathrm{CVC}$ increased from $28.51 \%$ to $41.15 \%$ massecuite, which seems slightly less than $48 \%$ achieved by cooling crystallizers. We could consider the increase in the $\mathrm{CC}$ of $1^{\text {st }}$ strike after A CVC compensates for the slight decrease in $\mathrm{CC}$ of the $3^{\text {rd }}$ strike after $\mathrm{C} \mathrm{CVC}$ than that of the conventional scheme, which sustains overall sugar recovery and yield matches the beet operation standards.

The quantity of $3^{\text {rd }}$ strike massecuite is $7.28 \% \mathrm{OB}$ at brix $95 \%$ as shown form fig. II.1. So for $1500 \mathrm{~T} / \mathrm{h}$ slices beet, $3^{\text {rd }}$ strike massecuite equals $7.28 \times 15=109 \mathrm{~T} / \mathrm{h}$, and the required capacity for cooling at S.G. $1.5 \mathrm{t} / \mathrm{m} 3$ is $(109 / 1.5) \times 40=2908 \mathrm{~m} 3$. This along with another compartment for heating massecuite from 45 to $55^{\circ} \mathrm{C}$ is with heating rate $5^{\circ} \mathrm{C}$, so the capacity of heating compartment equals $(109 / 1.5) \times 2=145 \mathrm{~m} 3$. The required cooling crystallizer capacity $=2908+145=3053 \mathrm{~m} 3$, the common vertical cooling crystallizer capacity is $500 \mathrm{~m} 3$, so six cooling crystallizers are required.

The required numbers as per the recommended retentions in CVC vessels are seven, distributed as two for $1^{\text {st }}$ strike boiling, two for $2^{\text {nd }}$ strike boiling, and three for $3^{\text {rd }}$ strike boiling; horizontal CVC volume is $220 \mathrm{~m} 3$, so total CVC capacity $=220 \times 7=1540$ $\mathrm{m} 3$, which represents the half capacity of cooling crystallizers. CAPEX of cooling crystallizers involving vessels, cooling and heating circuits, rotating shafts, and its big hydraulic drives and 
massecuite pumps are higher than CAPEX of CVC. While OPEX of both systems is nearly the same especially when creating the required deep vacuum for $\mathrm{CVC}$ operation by vapors condensation through water jet condenser and vacuum pump. From the technical point of view, CVC is applicable to be used in place of $\mathrm{C}$ cooling crystallizers and could be optimized for the highest efficiency of sucrose exhaustion to reduce its working numbers.

\section{Summary}

Early attempts have been done with vacuum/flash cooling crystallization CVC on sugar run-offs, which showed good results in terms of steam and energy cost-saving and sugar yield and quality improvement. Currently, the CVC process is successfully working in $1^{\text {st }}$ and $2^{\text {nd }}$ strikes for white sugar production in few European sugar plants. Series of continuous cooling crystallization and CVC pilot tests on cane sugar refinery streams at Al Khaleej sugar company AKS confirmed previously reported results and pushed AKS management to use this efficient technology for its new beet sugar project plant Canal sugar in Egypt in white sugar production in place of $\mathrm{C}$ cooling crystallizers.

Design and modeling of canal sugar plant crystallization scheme including new sugar crystallizers that run under deep vacuum and CVC are generated based on linear crystal growth approach. The theoretical results point out there is an increase in the crystal growth after CVCs of $1^{\text {st }}, 2^{\text {nd }}$, and $3^{\text {rd }}$ strikes by 16.7 , 11.3 , and $44.4 \%$ of original massecuite, respectively. This crystal growth increase represents total crystal content 59.6, 50.5, and 41.2 $\%$ massecuite of $1^{\text {st }}, 2^{\text {nd }}$, and $3^{\text {rd }}$ strikes, respectively slightly higher than crystal content conventionally performed under higher vacuum pressure, except $3^{\text {rd }}$ strike, lower than $48 \%$, achieved after $\mathrm{C}$ cooling crystallizers in reality. The increase in crystal content of $1^{\text {st }}$ and $2^{\text {nd }}$ strikes after CVCs than that of conventional process compensates the slight decrease in $\mathrm{CC}$ of the $3^{\text {rd }}$ strike after $\mathrm{C}$ CVC, which sustains overall sugar recovery $( \pm 83 \%)$, sugar yield $( \pm 15 \%)$, and molasses loss $( \pm 2.8 \%$ O.B.) within the beet sugar operation standards. 
The generated theoretical results show that steam and energy consumption of efficient European beet sugar plants represent $25 \%$ O.B. and $0.87 \mathrm{MJ} /$ ton of beet respectively, could be reduced to $17.5 \%$ O.B. and $0.61 \mathrm{MJ} /$ ton of beet with proceeding sugar crystallization under deep vacuum followed by applying CVC approach; while electrical consumption will be higher than $33 \mathrm{Kwh} /$ ton of beet because of high electricity of MVRs.

From a technical and practical point of views, continuous vacuum cooling crystallization is an efficient technology to be incorporated in the beet sugar industry for white sugar production optimization in terms of cost reduction and improved productivity and quality also in place of $\mathrm{C}$ cooling crystallizers in terms of low CABEX and OPEX and high reliability.

\section{References}

[1] Vavrinecz, G. (1978/79): Sugar Technol. Rev.6.117-129.

[2] Tuzhilikn VI, Balykhin MG, Lukin ND, Kovalyonok VA, and Gorbatov VM, "New Technologies of crystallization of sucrose as a fundamental factor of increase in economic efficiency of sugar branch", (2018), J Adv Food Techol 1(2): 204.

[3] Mantovani G.; Sgualdino, G.(1988): Zuckerindusteri 118, 137-142

[4] Reinefeld, E. (1986): Zuckerindusteri 111, 309-31.

[5] Hakan Gros, Teuvo Kilpio, Juha Nurmi, (2001), "Continuous cooling crystallization from solution", Powder Technology 121(1),106-115.

[6] Brunner, H.R.; Geckert, K.; Frankenfeld, Th.; Tschersich, J.; Nitsche, $W$. (1992): Zuckerindustrie 117, 446-454.

[7] Cuel, J.; Longue - Epee, C.(1984c): Int. Sugar J. 86, 109-113.

[8] Maurandi, V.; B.; Rossi, A. (1986): Zuckerindustrie 111, 5558. Bia, O., (1987): Zuckerindustrie 112, 518-524. 
[9] Osama Z.; Yassien M.T.; Ibrahim D. A.; Sherif T. Amin USCE, (2015),

"Sugar crystallization in low temperatures: The theory and practice by advanced sugar crystallization control program", SIT \#1113, SIT Proceeding.

[10] Yassien M.T.; Ibrahim D. A, Osama Z.; (2109), "Cooling crystallization opportunities for white sugar production", Egyptian sugar journal/Faculty of sugar and integrated industries technology, (FSIIT) / Vol 12 78-92.

[11] Andreas Lehnberger, Fahmi Brahim, Reinhold Hempelmann, BMA, Germany, (2017), "Operation of mills with low steam demand: Challenges and success in evaporator station and pan house", Proc Aust Soc Cane Technol Vol 39.

[12] Chris Mayhew, Carlton Haynes, Rober Howe, David Cooper, and Craig Parker, British sugar, (2018), "Developments in the reliability of cooling crystallizers performance" SIT proceeding from the 77th Technical Conference, Florida, USA.

[13] Murphy, A.; Punter, A.G.; Thompson, P,D, (1991): Int. Sugar J. 93, 33-38, 52-55, 79-81, 86, 95-96, 97-98.

[14] R Broadfoot, D Rackemann and D Moller, Queensland University of Thenology, Australia, (2018), "Why the emerging strong interest in vertical continuous pans?", Agribusiness Intelligence, Informa.

[15] Phil Thompson C.Eng. M.I.Chem.E., Sugar Knowledge International Ltd, UK, (1999), "Reducing Energy Consumption in beet factories: the European experience and its application to North America", ASSBT Proceeding.

[16] Development of a linear crystal growth approach, Chris Mayhew, Carlton Haynes, Robert Howe, Craig Parker, and Chris Rhoten, No. 11, (2017), Sugar industry 142/ 637-637. 
المفص العربي

تنفيذ هبردات بلورة السكر بالتفريغ بدلا هن استخدام هبردات البلورة التقليدية بطبخ ع لإنتاج السكر الابيض وتوفير استهلاك هون

الطاقة بصناعة السكر.

ياسين همد تيميرك ' - ابراهيم دردير عبد الالهّ2 - اساهه زين العابدين 3

$$
\begin{aligned}
& \text { لـلية العلوم - مبامعة اسبوط - مصر. } \\
& \text { شثركة السكر والصنا عات التكاملية بالهوامدية - مصر. } \\
& \text { شركة الفليج للسكر - جبال على - الامارات - دبي. . }
\end{aligned}
$$

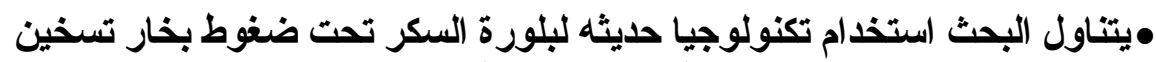

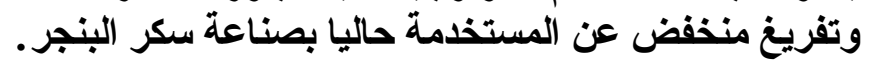

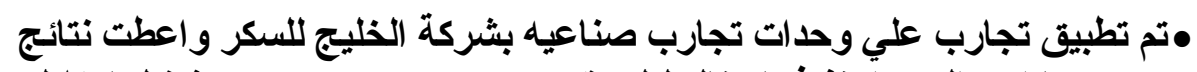

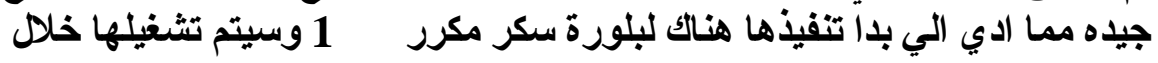
.2021

• هذه التكنولوجيا لبلورة السكر تحت ضغوط بخار وتفريخ منخفضه تم تنفيذها ايضا

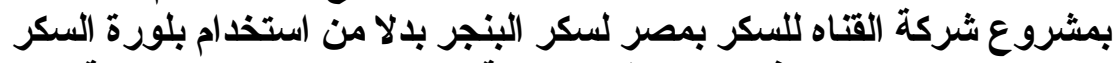

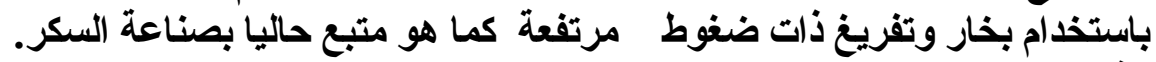

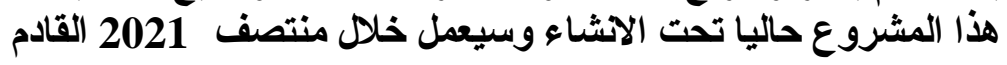

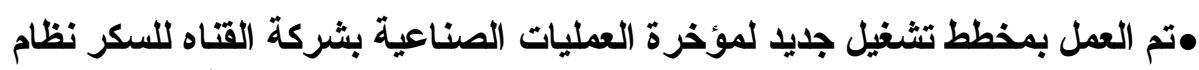

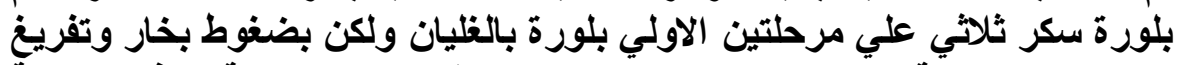

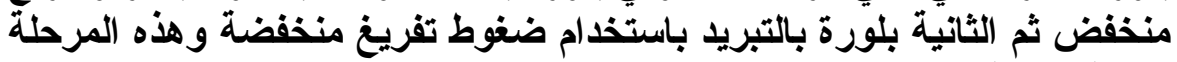

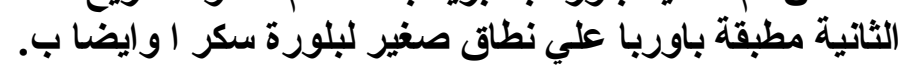

•اثبتت الدراسة نجاح هذه التكنولوجيا الجديدة بخفض استهلاك الطاقة بصناعة

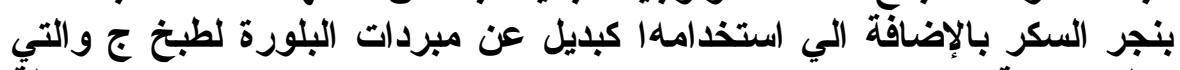

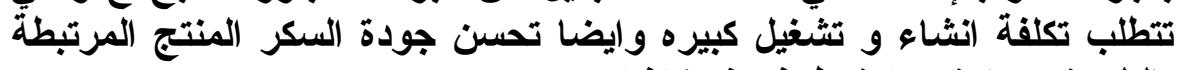
بالبلورة بحر ارة و ضغوط تفريغ منخفضه.

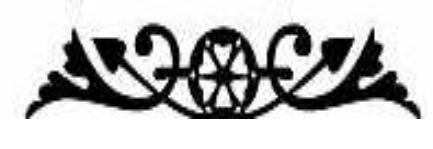

